\title{
アルキルトリフェニルホスホニウムイオンのろ紙電気泳動
}

\author{
蒔田＼cjkstart桂, 奥山 剛, 安藤 文雄, 䋶纈 銃吾*
}

中部大学工学部応用化学科（テ487-8501 春日井市松本町 1200）

\section{Paper Electrophoresis of Alkyl Triphenylphosphonium Ions}

\author{
Kei MAKITA, Takeshi OKUYAMA, Fumio ANDo, and Jugo KoKETSU*
}

\begin{abstract}
Department of Applied Chemistry, College of Engineering, Chubu University (1200 Matsumoto, Kasugai, Aichi 487 8501, Japan)

Received June 14, 2000 ; Accepted July 26, 2000

In order to use for separation and qualitative analysis of phosphonium ions, the paper electrophoresis was applied on the fourteen triphenylphosphonium ions which have the linear chain alkyl substituents from methyl to octyl groups on the phosphorus atom along with benzyl, acetylmethyl, benzoylmethyl, methoxycarbonylmethyl, ethoxycarbonylmethyl, cyanomethyl substituents. Good correlations have been found between the average mobilities and the molecular weights.
\end{abstract}

Key Words : Electrophoresis, Phosphonium Ions

\section{1 緒 言}

電場の下で荷電した溶質を移動させて物質を分離するゾー ン電気泳動法のうち，乃紙を支持材質として用いるろ紙電気 泳動法はこれまで生体高分子であるタンパク質, DNA，糖 類などの簡便な定性分析法として利用され，有機化合物にお けるシリカゲル薄層クロマトグラフィーと似た幅広い役割を 担ってきた ${ }^{1-3}$ 。近年になり，これら生体高分子分析にお いては寒天やポリアクリルアミドゲルを担体とするゲル電気 泳動法 ${ }^{4}$ やキャピラリー電気泳動法 ${ }^{5}$ が正確な結果を与える ことから, 万紙電気泳動法が分析方法として応用されること は希となっているのが害状である.

しかし，乃紙を用いる方法は手軽であり，適当な条件を選 ベば穏和な条件下，極めて高い分離能を示すことが知られて いることから, 近年においてもアミノ酸を含む窒素含有化合 物 ${ }^{6-10)}$ やピリジニウムイオン11)，フエノール12,13)，金属イオ ン13-19), リン酸誘導体 ${ }^{20-22)}$ ，イオウ誘導体23)などに応用さ れた例が報告されている.しかしホスホニウムイオンのろ紙 電気泳動法による分離についてはこれまで全く報告されてい ない.

ろ紙を用いる利点は, ゲルまたはキャピラリー電気泳動法 において適切な発色反応が困難な物質についても, 万紙上で の化学反応を利用できることである．特に有機物質について は,ゲル上に吸着した物質の検出は特有な化学反応を利用で きる場合を除いて，一般に検出が困難であるのに反し，ろ紙 上では最終的にはシリカゲル薄層クロマトグラフィーで応用 される万能型のヨウ素蒸気に曝露し発色させることも可能で あり，この検出が容易である利点を生かすことができると考 えられる。

実験方法として, $\mathrm{pH}$ を一定にした緩衝液を媒体として,
一定の電圧下での電気泳動における泳動距離（以下 EL と略 す）を求め, 基準試料の泳動距離に对する相対泳動距離を求 めた。この相対泳動距離から得た相対易動度（以下 ARM と 略す）と分子量（以下 MW と略す）との相関を検討した.

\section{1 実験装置と実験材料}

\section{2 実 験}

電気泳動汭アドンテック社製 EF-200 型ろ紙電気泳動装 置を使用した．定電圧印加には株式会社マリソル社の高精度 安定化電源証置 MP-7612 D を用いた. 電流計は内田洋行製 ミリアンペア計 TM-500を使用した。

${ }^{31}$ P-NMR は日本電子 JNM-A シリーズを用いて $\mathrm{CDCl}_{3}$ を 溶媒として測定した. 化学シフト $(\delta \mathrm{Pppm})$ は $85 \%$ リン酸 を基準とした。

質量スペクトルは直接試料導入装置を備えた電子科学株式 会社製 MS 型検出器 EMD-05B を用いた。

万秪電気泳動には Toyo Roshi Kaisha Ltd 製 ADVANTEC 50 番 $\left(400 \times 400 \mathrm{~mm}^{2}\right)$ のろ紙を使用した。

\section{2 反応試薬}

本研究ではトリフェニルホスフィンに各種臭化アルキルを 反応させて得られたホスホニウムイオンのろ紙電気泳動につ いて検討した。これらのホスホニウムイオンはこれまで多く

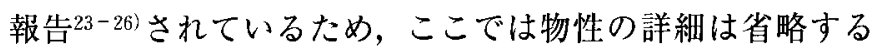
が，その構造は質量分析により各オニウムイオンの陽イオン 部に相当するペアレントピークを検出したほか, Table 3 に 示した ${ }^{31} \mathrm{P}-\mathrm{NMR}$ スペタトルデータにより確認した. 各種置 換基を有するホスホニウムイオンの略号は以下の通りである. 臭化トリフェニルメチルホスホニウム（以下 Meと略記す る)，以下直鎖アルキル基を用いたエチル（Et），プロピル 
$(\mathrm{Pr})$, ブチル $(\mathrm{Bu})$, ペンチル $(\mathrm{Pen})$, ヘキシル $(\mathrm{Hex})$, ヘプチル (Hep), オクチル (Oct) のほか, ベンジル (Bn), アセチルメチル $(\mathrm{Acm})$, ベンゾイルメチル $(\mathrm{Bzm})$, メト キシカルボニルメチル $(\mathrm{Mcm})$, エトキシカルボニルメチル $(\mathrm{Ecm})$, シアノメチル $(\mathrm{NCm})$ の各ホスホニウムイオンを 合成し泳動に用いた。緩衝液に用いたピリジン, ギ酸, 酢酸 と, ホスホニウムイオンの検出に用いたブタノール，ニンヒ ドリン，ヨウ素は市販品をそのまま使用した。

泳動には次の 2 種類の $\mathrm{pH}$ を持つ緩衝液を使用した。

pH 1.9: ギ酸 5 : 酢酸 $15:$ 水 80 (体積)

pH 3.1：ピリジン 1 : 酢酸 10 : 水 89 (体積)

\section{3 電気泳動法}

すき目方向に長辺ができる様に $400 \times 150 \mathrm{~mm}^{2}$ の大きさに ろ紙を切断し，上下 $90 \mathrm{~mm}$ を残した中央部分に切り込みを 入れて，幅 $18 \mathrm{~mm}$ の展開部が 5 列ある打ち抜きろ紙を作製 した.このろ紙を所定の緩衝液に浸したのち，泳動装置に装 着した。泳動装置に蓋をして15 分問放置してろ紙上の湿潤 状態を均一化した。あらかじめ同じ緩衝液に溶解したホスホ ニウムイオンの試料溶液 $50 \mu \mathrm{l}$ を，ピペットで陽極から 80 $\mathrm{mm}$ の位置に塗布した。試料塗布後, 泳動装置に蓋をして 5 分放置したのち所定の電圧で泳動を開始した.

1 時間の泳動後，ろ紙をはずし $120^{\circ} \mathrm{C}$ に設定した乾燥器で 20 分乾燥した。このろ紙をガラス容器に充満させたヨウ素 蒸気に曝露する方法で発色させることを試みたが, 発色に適 さない試料が散見されたため，タンパク質の発色に利用され る $2 \%$ ニンヒドリン一水飽和ブタノール溶液を噴霧し, 風乾 後 20 分 $120^{\circ} \mathrm{C} に て$ 乾燥する事により青紫色に発色すること を確かめた。以後この発色法を用いて泳動位置を検出した.

泳動距離は泳動時の温度などの差異により変動する可能性 があるため，エチルトリフェニルホスホニウムイオン $(\mathrm{Et})$ を基準物質に選び,この泳動距離を基準として他のホスホニ ウムイオンの泳動距離との比を用いた。 1 種類の試料につき この分析を 5 回繰り返し，その平均值を取って比較検討した.

\section{3 実験結果}

\section{1 泳動電压と緩衝液の $\mathrm{pH}$ が泳動距離に及ぼす影響}

Table 1 に Et E Ecm の試料を $\mathrm{pH} 3.1$ の緩衝液を用いて 泳動電圧を 200，400，600 Vに設定し，1 時間泳動した泳動 距離 (EL mm) を示す. 3 回測定した標準偏差: (SD) は比 較的小さく，泳動距離の平均値 (AEL mm) は印加した電 圧 Vにほほ正比例することが分かった。

Table 1 Effect of the input electric voltage on the electrophoresis mobility (EL and AEL).

\begin{tabular}{|c|c|c|c|c|c|c|}
\hline $\begin{array}{l}\text { Phosphonium } \\
\text { Ion }\end{array}$ & $\begin{array}{l}\text { Voltage } \\
{[\text { V] }}\end{array}$ & $\begin{array}{c}\text { EL1 } \\
{[\mathrm{mm}]}\end{array}$ & $\begin{array}{c}\text { EL2 } \\
{[\mathrm{mm}]}\end{array}$ & $\begin{array}{l}\text { EL3 } \\
{[\mathrm{mm}]}\end{array}$ & $\begin{array}{l}\mathrm{AEL} \\
{[\mathrm{mm}]}\end{array}$ & $\mathrm{SD}$ \\
\hline \multirow{3}{*}{$\begin{array}{c}\mathrm{Ph}_{3} \mathrm{P}^{+} \mathrm{Et} \\
(\mathrm{Et})\end{array}$} & 200 & 29.9 & 28.6 & 30.1 & 29.5 & 0.814 \\
\hline & 400 & 65.9 & 66.3 & 66.8 & 66.3 & 0.451 \\
\hline & 600 & 101.5 & 102.3 & 99.5 & 101.1 & 1.442 \\
\hline \multirow{3}{*}{$\begin{array}{c}\mathrm{Ph}_{3} \mathrm{P}^{+} \mathrm{CH}_{2} \mathrm{CO}_{2} \mathrm{Et} \\
(\mathrm{Ecm})\end{array}$} & 200 & 28.9 & 29.4 & 29.0 & 29.1 & 0.227 \\
\hline & 400 & 65.2 & 64.0 & 63.9 & 64.4 & 0.739 \\
\hline & 600 & 99.6 & 97.7 & 98.5 & 98.6 & 1.001 \\
\hline
\end{tabular}

Table 2 Effect of the $\mathrm{pH}$ of buffer solutions on the electrophoresis mobility (EL and $\mathrm{AEL}$ ) of $\mathrm{Ph}_{3} \mathrm{P}^{+} \mathrm{Et}(\mathrm{Et})$.

\begin{tabular}{|c|c|c|c|c|c|}
\hline $\mathrm{pH}$ & $\begin{array}{c}\mathrm{EL} 1 \\
{[\mathrm{~mm}]}\end{array}$ & $\begin{array}{c}\text { EL2 } \\
{[\mathrm{mm}]}\end{array}$ & $\begin{array}{c}\mathrm{EL3} \\
{[\mathrm{mm}]}\end{array}$ & $\begin{array}{c}\mathrm{AEL} \\
{[\mathrm{mm}]}\end{array}$ & $\mathrm{SD}$ \\
\hline 1.9 & 99.6 & 100.3 & 101.5 & 100.5 & 0.96 \\
\hline 3.1 & 101.5 & 102.3 & 99.5 & 101.1 & 1.44 \\
\hline
\end{tabular}

Table $3 \quad{ }^{31} \mathrm{P}-\mathrm{NMR}$ chemical shifts and average relative mobility (ARM) of alkyl triphenylphosphonium ions at $\mathrm{pH} 1.9$ and 3.1 .

\begin{tabular}{cccccccc}
\hline & & & \multicolumn{2}{c}{$\mathrm{pH}=1.9$} & & \multicolumn{2}{c}{$\mathrm{pH}=3.1$} \\
\cline { 7 - 8 } \cline { 6 - 7 } $\mathrm{R}$ & $\delta \mathrm{P}[\mathrm{ppm}]$ & & $\mathrm{ARM}$ & $\mathrm{SD}$ & & $\mathrm{ARM}$ & $\mathrm{SD}$ \\
\cline { 1 - 3 } \cline { 6 - 7 } $\mathrm{Me}$ & 22.57 & & 1.034 & 0.037 & & 1.002 & 0.021 \\
$\mathrm{Et}$ & 27.24 & & 1.000 & & & 1.000 & \\
$\mathrm{Pr}$ & 24.88 & & 0.978 & 0.016 & & 0.972 & 0.029 \\
$\mathrm{Bu}$ & 27.02 & & 0.950 & 0.014 & & 0.959 & 0.014 \\
$\mathrm{Pen}$ & 25.41 & & 0.945 & 0.012 & & 0.953 & 0.005 \\
$\mathrm{Hex}$ & 24.77 & & 0.944 & 0.011 & & 0.948 & 0.007 \\
$\mathrm{Hep}$ & 24.97 & & 0.937 & 0.006 & & 0.935 & 0.007 \\
$\mathrm{Oct}$ & 24.83 & & 0.926 & 0.004 & & 0.930 & 0.009 \\
$\mathrm{Bn}$ & 23.84 & & 0.922 & 0.025 & & 0.943 & 0.016 \\
$\mathrm{Acm}$ & 20.47 & & 0.977 & 0.008 & & 0.981 & 0.013 \\
$\mathrm{Bzm}$ & 22.59 & & 0.908 & 0.009 & & 0.927 & 0.013 \\
$\mathrm{Mcm}$ & 21.44 & & 0.964 & 0.017 & & 0.972 & 0.009 \\
$\mathrm{Ecm}$ & 21.57 & & 0.961 & 0.006 & & 0.965 & 0.005 \\
$\mathrm{NCm}$ & 22.41 & 0.976 & 0.003 & & 0.996 & 0.021 \\
\hline
\end{tabular}

また，Etを用いて pH $1.9 と 3.1$ の場合の泳動距離を比較 した結果を Table 2 に示す. 緩衝液の $\mathrm{pH} に よ り$ 泳動距離に 大きな差異はない．またこの場合測定した電流値は泳動シー ト全体で 20〜24 mAの間で変動したが, $\mathrm{pH}$ による電流值の 違いは認められなかった。

\section{2 各種置換基を有するホスホニウムイオンの電気泳動}

上に述べた条件検討を基にして，以下の泳動では pH 1.9 と 3.1 の緩衝液を用い, 印加電圧 $600 \mathrm{~V}$ で 1 時間の泳動を行 った. Table 3 には同じ試料に対し，pH 1.9 と 3.1 の緩衝液 を用いて 5 回の泳動を試みた場合の，エチルトリフェニルホ

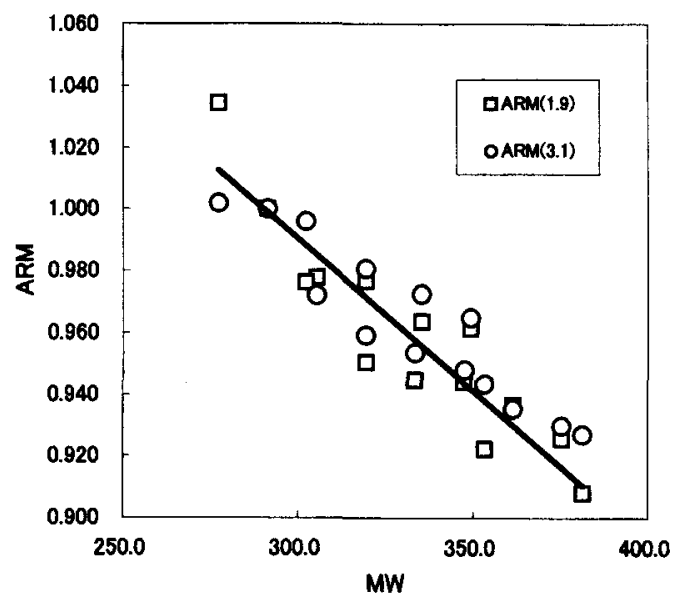

Fig. 1 Dependence of average relative mobility (ARM) on the molecular weight (MW). 
スホニウムイオンの泳動距離（ELEt）に対する相対的な值で ある易動度（ELR/ $\left.\mathrm{EL}_{\mathrm{Et}}\right)$ の 5 回の平均易動度（ARM）を示 した．各測定の標準偏差（SD）は小さく精度は高い.

さらに分子量 (MW) と ARM の相関関係を Fig. 1 に示す。.

\section{4 考 察}

有機リン化合物の定性分析には，一般的なクロマトグラフ イーやスペクトルによる分析方法が適用でき応用されてき た25)。しかし，ホスホニウムイオンのろ紙電気泳動法を用い た検出については全く報告がなされていない，本実験では各 種ホスホニウムイオンを合成し，それらのろ紙電気泳動法の 易動度を求め，分子量との相関を検討した。

ホスホニウムイオンのろ紙上での検出にはニンヒドリンー ブタノール溶液が適応できる。この発色機構の詳細は十分に は明らかではないが，ニンヒドリンの加熱により生成する反 応性の高いトリカルボニル基とカルボニル酸素への親和性の 高いリン原子の反応生成物が発色物質を与えると考えられる. ニンヒドリンによる各スポットの発色は最初青紫色を示すが, 時間の経過と共に褐色へと変化する。この発色は明暸に識別 可能でありホスホニウムイオンの種類などへの依存性は認め られず，この方法がホスホニウムイオンの沉用的な検出法と して適していると考えられる。

電気泳動は $23^{\circ} \mathrm{C}$ の恒温に温度調節の可能な場所で行い, 装置自体に温度調節機能は備えていない状態で行った，泳動 の条件としては, pH 1.9 のギ酸一酢酸と 3.1 のピリジン-酢酸 系の緩衝液を用いた場合, 泳動距離, 泳動時の電流值に大き な差異は認められなかった。また，電圧変化の泳動距離への 影響を求めたところ, Table 1 に示すように $600 \mathrm{~V}, 1$ 時問 の条件が適当であることが判明した。電流值は $20 \sim 24 \mathrm{~mA}$ で大きな変動はなく, ジュール熱の発生も泳動距離に影響を 与えるほどのものではなかった。しかし泳動条件変化の影響 を打ち消すため，標準物質としてエチルトリフェニルホスホ ニウムイオンの泳動を同じろ紙上で行い，この值を基準とし て相対的な泳動距離の平均值を用いて平均易動度 (ARM) を得た。この值はアルキル置換基の種類により変動し, 構造 変化の影響を受ける.この易動度と分子量との相関を検討し た. 分子の大きさを反映する分子量との相関は,

$$
\mathrm{ARM}=a \times\left(\mathrm{MW} / 10^{3}\right)+b
$$

を用いると比例定数 $a$, 定数項 $b$ と単相関係数 $r$ および分散 $s$ は次のように計算される。

$$
\begin{array}{rlrl}
\mathrm{pH}=1.9: a & =-0.981 & b & =1.29 \\
r & =0.923 & s & =0.012 \\
\mathrm{pH}=3.1: & a=-0.869 & b & =1.22 \\
r & =0.937 & s & =0.007
\end{array}
$$

两 $\mathrm{pH}$ での単相関係数はいずれも良好であり $s$ 值も小さく, 有意の相関が存在する。また，相関の勾配が負となることは 分子量が大きくなるほど電気泳動の易動度に対し抵抗として 作用することを意味している.

これらの結果から，ろ紙電気泳動法を用いて易動度を比較 することにより，分子の大きさの変化に基づく分離分析が可 能であり，この電気泳動法がホスホニウムイオンの定性に有
効な手段であると考えられる。

\section{5 結 論}

1 万紙上に展開したホスホニウムイオンの発色法としてニ ンヒドリン発色法が有効であることを見いだした。

214 種類のホスホニウムイオンのろ紙電気泳動を行ったと ころ，ギ酸一酢酸掞よびピリジン一酢酸系緩衝液を用いる ことにより適切な相対易動度が求められた。

3 この相対易動度と分子パラメーターとしての分子量と置 換基全般に渡って良好な相関が成立した。

\section{文 献}

1) R. J. Block, E. L. Durrum, and G. Zweig, A Laboratory Manual of Paper Chromatography and Paper Electrophoresis, Academic Press, New York (1955).

2) L. P. Ribeiro, E. Matidieri, and O. R. Affonso, Paper Electrophoresis, Elsevier, London (1961).

3) S. Fanali and L. Ossicini, J. Chromatogr., 287, 148 (1984).

4) H. Terada, Denki Eidouhou, Kiso To Zikken, Hirokawa, Tokyo (1989), (in Japanese).

5) S. Honda and S. Terabe, Kyapirari Denkieidou, Koudansya, Tokyo (1995), (in Japanese).

6) A. R. Hayman and D. O. Gray, J. Chromatogr., 370, 194 (1986).

7) R. L. Munier and S. Meunier, Chromatographia, 11, 508 (1978).

8) J. Franc and K. Pospisilova, J. Chromatogr., 74, 157 (1972).

9) H. Wagner and H. Lehmann, Fresenius' Z. Anal. Chem., 283, 115 (1977).

10) Y. Kitaoka, J. Chromatogr., 147, 449 (1978).

11) E. Bald, Fresenius' Z. Anal. Chem., 320, 776 (1985).

12) E. Bald, Fresenius' Z. Anal. Chem., 305, 415 (1981).

13) S. A. Navi, A. Sikarwar, and A. Gupta, Acta Chromatogr., 8, 162 (1998).

14) N. M. Cvjetian and K. O. Jovanovi, J. Chromatogr., 94, 349 (1974).

15) R. K. P. Singh, J. R. Yadava, P. C. Yadava, and K. L. Yadava, Z. Phys. Chem., 264, 464 (1983).

16) A. K. Misra, R. P. S. Rajput, V. K. Maheshwari, and D. K. Misra, J. Planar Chromatogr., 1990, 256.

17) J. C. Nasi and C. R. Tirapelli, Rev. Bras. Farm., 77, 173 (1996).

18) V. Pop, G. Marcu, and A. Batar, Rev. Chim . (Bucharest), 48, 943 (11997).

19) J. Maslowska and R. Sikorski, Zesz. Nork.-Polytech. Lodz., Chem. Spozyw. Biotechnol., 60, 19 (1998).

20) H. Jensen, F. Habault, A. M. Lacoste, A. Cassaigne, and E. Neuzil, J. Chromatogr., 132, 556 (1977).

21) R. C. Johnson, R. M. C. Dawson, and N. Freinkel, $J$. Chromatogr., 187, 235 (1980).

22) L. Xu, H. Wang, and Q. Su, Comput. Chem., 16, 195 (1992).

23) J. L. Frahn, J. Chromatogr., 318, 446 (1985).

24) P. Beck, "Organic Phosphorus Compounds (Eds. G. M. Kosolapoff and L. Maier)” Wiley-Interscience, New York, Vol. 2, Chap. 2 (1972).

25) R. Okazaki, Yuuki Rin Kagoubutsu (Ed. Yuuki Gousei Kagaku Kyoukai) Gihoudou Tokyo, p.288 (1971), (in Japanese).

26) Kinki Kagaku Kougyoukai, Yuuki Kinzoku Handobukku (Organo Metallic Handbook), Asakura Syoten, Tokyo, p. 530 (1972), (in Japanese). 